\title{
Identification of FLT3 and NPM1 Mutations in Patients with Acute Myeloid Leukaemia
}

\author{
Yuslina Mat Yusoff*, Zahidah Abu Seman, Norodiyah Othman, Nor Rizan \\ Kamaluddin, Ezalia Esa, Nor Amalina Zulkiply, Julia Abdullah, Zubaidah \\ Zakaria
}

\begin{abstract}
Objective: The most frequent acquired molecular abnormalities and important prognostic indicators in patients with Acute Myeloid Leukaemia (AML) are fms-like tyrosine kinase-3 gene (FLT3) and nucleophosmin-1 (NPM1) mutations. Our study aims to develop a cost effective and comprehensive in-house conventional PCR method for detection of FLT3-ITD, FLT3-D835 and NPM1 mutations and to evaluate the frequency of these mutations in patients with cytogenetically normal (CN) AML in our population. Methods: A total of 199 samples from AML patients (95 women, $104 \mathrm{men}$ ) were included in the study. Mutation analyses were performed using polymerase chain reaction (PCR) and gene sequencing. Result: Sixty-eight patients were positive for the mutations. FLT3-ITD mutations were detected in 32 patients (16.1\%), followed by FLT3-D835 in 5 (2.5\%) and NPM1 in 54 (27.1\%). Double mutations of NPM1 and FLT3-ITD were detected in 23 cases (11.6\%). Assays validation were performed using Sanger sequencing and showed $100 \%$ concordance with in house method. Conclusion: The optimized in-house PCR assays for the detection of FLT3-ITD, FLT3-D835 and NPM1 mutations in AML patients were robust, less labour intensive and cost effective. These assays can be used as diagnostic tools for mutation detection in AML patients since identification of these mutations are important for prognostication and optimization of patient care.
\end{abstract}

Keywords: Acute myeloid leukaemia; FLT3 gene- FLT3-ITD gene- FLT3-D835 gene- NPM1 gene

Asian Pac J Cancer Prev, 20 (6), 1749-1755

\section{Introduction}

Acute myeloid Leukaemia (AML) is a biologically heterogeneous disease resulting from clonal expansion and loss of differentiation of the haematopoietic progenitor cells (myeloblasts), with complex network of cytogenetic aberrations and molecular mutations (Lowenberg et al., 1999; Estey et al., 2006; Shipley et al., 2009). These genetic markers are the basis for categorization of cases within distinct subgroups and are highly relevant for prediction of prognosis and also for therapeutic decisions in AML (Medinger et al 2017; Torsten et al., 2008). Cytogenetics, age and performance status are well known factors which determine prognosis and therapy. It has long been appreciated that cytogenetic factors are independent predictors for the prognosis of AML patients (Schiffer and Stone, 2003). However, for 50\% of AML patients, no cytogenetic markers can be found (Döhner et al., 2010; Schlenk et al., 2008; Grimwade et al., 2010; Mrozek et al., 2004). Genetic mutations that escape cytogenetic detection have increasingly been discovered, and these mutations may serve as potential markers for prognostication in
AML and can be used as molecular targets for precision medicine (Foran, 2010).

Fms-like tyrosine kinase-3 gene (FLT3) and nucleophosmin-1 (NPM1) mutations are the most frequent acquired molecular abnormalities in cytogenetically normal (CN) AML (Falini et al., 2005; Renneville et al., 2008). Many studies have shown that FLT3 gene plays an important role in the proliferation, differentiation and survival of multipotent stem cells. This gene is located at chromosome 13q12 and it encodes for a membrane bound receptor tyrosine kinase and was expressed normally by myeloid and lymphoid progenitor cells. It consists of five immunoglobulin-like extracellular domains that further divides into a single transmembrane domain, a juxtamembrane domain (JMD) and intracellular domains. Mutation of these genes causes poor prognosis in both adult and childhood AML. Two major types of FLT3 mutations are found among AML patients namely the internal tandem duplication (ITD) and point mutation in tyrosine kinase domain (D835) (Levis, 2013). FLT3-ITD involves insertion of 6 to 180 nucleotides into exon 11 and exon 12 in the juxtamembrane region (JM) (Markovic 
et al., 2005), which always lead to in frame transcript (Hayakawa et al., 2000). Meanwhile, FLT3-D835 involves missense point mutation at codon 835 which alters the aspartic acid residue and causes constitutive activation of FLT3 receptor (Abu-Duhier et al., 2001). These mutations make up for 20 to 37\% (Chirayu et al., 2005; Wang et al., 2005) and 7.7\% (Yamamoto et al., 2001) of total AML respectively.

Nucleoplasmin (NPM1) is a phosphoprotein that shuttles continuously between the nucleus and cytoplasm and is involved in regulation of the ARF-p53-tumor suppressor pathway (Borer et al., 1989). NPM1 gene is located on 5q35.1 and contains 12 exons (Morris et al., 1994). Mutation in this gene leads to aberrant cytoplasmic localization of nucleoplasmin protein (Falini et al., 2005). NPM1 mutations are present in $50 \%$ to $60 \%$ of patients with CN-AML and $30 \%$ to $35 \%$ of all AML cases (Verhaak et al., 2005; Ivey et al., 2016). More than $95 \%$ of the NPM1 mutations consist of a 4-base pair (bp) insertion at position 863 . The most frequently occurring have been named type A (c.860_863dupTCTG), which accounts for $69 \%$ to $80 \%$ of adults cases, followed by type B (c.863_864insCATG) which was found in $10 \%$ to $11 \%$ cases and type D (c.863_864insCCTG) in about 5\% to $10 \%$. The remaining types of mutations account for $10 \%$ to $12 \%$ of cases (Falini et al., 2005; Alpermann et al., 2016). There are at least 20 types of NPM1 mutations with 4-bp insertions (including type C) at the same position, and a minority of insertions at other locations in exon 12. (Falini et al., 2005; Thiede et al., 2006).

Early identification of FLT3 and NPM1 gene mutations helps clinician to provide up-front treatment regimens and therapeutic strategies for the AML patients. There are several commercially available kits for FLT3 and NPM1 gene mutations, however the available kits are relatively expensive. Therefore, there is a need to develop a simple, rapid, reliable and cost-effective test in the diagnostic testing. Our study aims to establish a cost effective and rapid polymerase chain reaction (PCR) method for routine diagnostic protocols. We also present the incidence of FLT3-ITD, FLT3-D835 and NPM1 mutations of CN-AML patients in our population.

\section{Materials and Methods}

\section{Samples and DNA Preparation}

One hundred and ninety-nine CN-AML patients were included in this study. FLT3-ITD, FLT3-D835 and NPM1 mutations testing were performed on peripheral blood and bone marrow aspirates samples. All samples were collected in accordance to the Ethics of Human research guidelines and DNA was extracted using the QIAmp DNA blood mini kit according to the manufacturer's instruction (Qiagen, Hilden, Germany).

\section{PCR amplification}

For mutational analysis of FLT3-ITD, FLT3-D835 and NPM1, genomic DNA of AML patients were amplified using primer sets as described previously (Dunna et al., 2010; Xu et al., 2005). The primers were synthesized by First BASE Laboratories Sdn Bhd, Singapore.
Primers for both assays were designed based on FLT3 gene which encodes a class III receptor tyrosine kinase that regulates haematopoiesis (Accession No: NM_004119.2). FLT3-ITD primers were designed between exon 14 and 15 of the FLT3 gene, with the amplified product size of 329 bp, while FLT3-D835 primers were designed for exon 20 of the FLT3 gene, which produced 114 bp products. NPM1 primers were designed to amplify a product size that contains the coding region of NPM1 exon 12 (Accession No: NM_002520).

FLT3-ITD PCR: Since FLT3-ITD mutation was located within exon 14 and 15, PCR amplification was performed using 5'- GCA ATT TAG GTA TGA AAG CCA GC -3' (ITD_14F) and 5'- CTT TCA GCA TTT TGA CGG CAA CC -3' (ITD_15R) primers. PCR was performed in a total volume $\overline{25} \mu \mathrm{l}$ of $1 \mathrm{X}$ Maxima Hot Start Taq buffer, $3 \mathrm{mM} \mathrm{MgCl2}, 0.2 \mathrm{mM}$ dNTPs, $0.8 \mu \mathrm{M}$ of ITD_14F and ITD_15R primers, 1.25 U Maxima Hot Start Taq polymerase and 50-100ng/ $\mu$ l of genomic DNA. The reaction was carried out through initial denaturation at $95^{\circ} \mathrm{C}$ for 7 minutes, followed by 35 cycles of denaturation at $94^{\circ} \mathrm{C}$ for 1 minute, annealing at $60^{\circ} \mathrm{C}$ for 45 seconds and extension at $72^{\circ} \mathrm{C}$ for 1 minute, and final extension at $72^{\circ} \mathrm{C}$ for 7 minutes.

FLT3-D835 PCR: Primers used for the D835 were 5'-CCG CCA GGA ACG TGC TTG-3' (D835_F) and 5'-GCA GCC TCA CAT TGC CCC-3' (D835_R). PCR was performed in a total volume $25 \mu \mathrm{l}$ of $1 \mathrm{X}$ Maxima Hot Start Taq buffer, $2 \mathrm{mM}$ Q-solution, $3 \mathrm{mM} \mathrm{MgCl}, 0.2 \mathrm{mM}$ dNTPs, $0.8 \mu \mathrm{M}$ of D835_F and D835_R primers, $1.25 \mathrm{U}$ Maxima Hot Start Taq polymerase and 50-100ng/ $\mu$ l of genomic DNA. Reaction was carried out through initial denaturation at $95^{\circ} \mathrm{C}$ for 9 minutes, followed by 35 cycles of denaturation at $94^{\circ} \mathrm{C}$ for 30 seconds, annealing at $59^{\circ} \mathrm{C}$ for 1 minute and extension at $72^{\circ} \mathrm{C}$ for 1 minute, and final extension at $72^{\circ} \mathrm{C}$ for 10 minutes. After amplification, 10 $\mu 1$ of PCR product was digested with $1 \mathrm{U}$ EcoRV enzyme and $2 \mathrm{X}$ digestion buffer. Digestion reaction was performed at $37^{\circ} \mathrm{C}$ for 15 minutes, followed by enzyme deactivation at $80^{\circ} \mathrm{C}$ for 20 minutes. PCR product for FLT3-ITD and FLT3-D835 were then visualized via Agilent Bioanalyzer 2100 System plus DNA 1000 LabChip kit (Agilent Technologies, CA, USA).

NPM1 PCR: Genomic DNA was amplified with 5'TTAACT CTC TGG TGG TAG AAT GAA-3' (NPM1_F) and 5'- TGT TAC AGA AAT GAA ATA AGA CGG-3' (NPM1_R) primers. PCR was performed in a total volume $20 \mu$ l of $1 \mathrm{X}$ Maxima Hot Start Taq buffer, $2.5 \mathrm{mM}$ $\mathrm{MgCl} 2,0.7 \mu \mathrm{M}$ of NPM1_F and NPM1_R primers, 1.25 U Maxima Hot Start Taq polymerase and 50-100ng/ $\mu$ l of genomic DNA. After an initial denaturation at $94^{\circ} \mathrm{C}$ for 3 minutes, DNA was amplified in 35 cycles at $95^{\circ} \mathrm{C}$ for 1 minute, $60^{\circ} \mathrm{C}$ for 45 seconds, $72^{\circ} \mathrm{C}$ for 2 minutes, followed by a final extension at $72^{\circ} \mathrm{C}$ for 7 minutes. PCR products were visualized under UV light after electrophoresis of 5 $\mu \mathrm{l}$ product in $4 \%$ agarose gel.

\section{Results}

PCR amplicon with ITD gene mutation showed different sizes of PCR products ( $\geq 329 \mathrm{bp}$ ) due to tandem 
repeat mutation which occurs at variable locations and different lengths in the ITD gene. Negative result produced $329 \mathrm{bp}$ band which indicates absence of FLT3-ITD mutation, while positive result produced bands larger than 329 bp which indicate presence of FLT3-ITD mutation. It has also been confirmed that the size of the ITD was always a multiple of three bases (Mills et al, 2005) (Figure 1 (a)).

Amplicon of FLT3-D835 gene was amplified and digested using EcoRV enzyme (GATATC) recognized position at 835 to produce $68 \mathrm{bp}$ and $46 \mathrm{bp}$ products. Digestion step is crucial to differentiate between normal and mutated samples. FLT3-D835 mutation changes the $\mathrm{G}$ to $\mathrm{T}$ base and modified the binding site of EcoRV. Thus, EcoRV cannot recognise the amplicon sequence and produced $112 \mathrm{bp}$ of PCR product (Figure 1 (b)).
FLT3 and NPMI Mutations in Acute Myeloid Leukaemia

Genomic fragment of NPM1 produced $215 \mathrm{bp}$ and $219 \mathrm{bp}$ for mutant NPM1 and 215 bp for wild-type NPM1 (Figure 1 (c)).

Evaluation of limit of detection for FLT3-ITD, FLT3-D835 and NPM1 primers were performed by serial dilution of DNA. DNA concentration limitation for detection of FLT3-ITD and FLT3-D835 primers were $0.4 \mathrm{ng}$ and $1.56 \mathrm{ng}$ respectively using Agilent 2100 Bioanalyzer (Figure $2(\mathrm{a}, \mathrm{b})$ ). DNA fragment of NPM1 primer, using PCR-agarose gel electrophoresis could detect 1.56 ng of the DNA concentration (Figure 2 (c)).

A total of 199 patients (104 men, 95 women) with $C N-A M L$ were included in this study. Their demographic features including age, race and gender was summarized as in Table 1. Mutations were detected in 68 patients (34.2\%), single mutation for FLT3-ITD was detected in

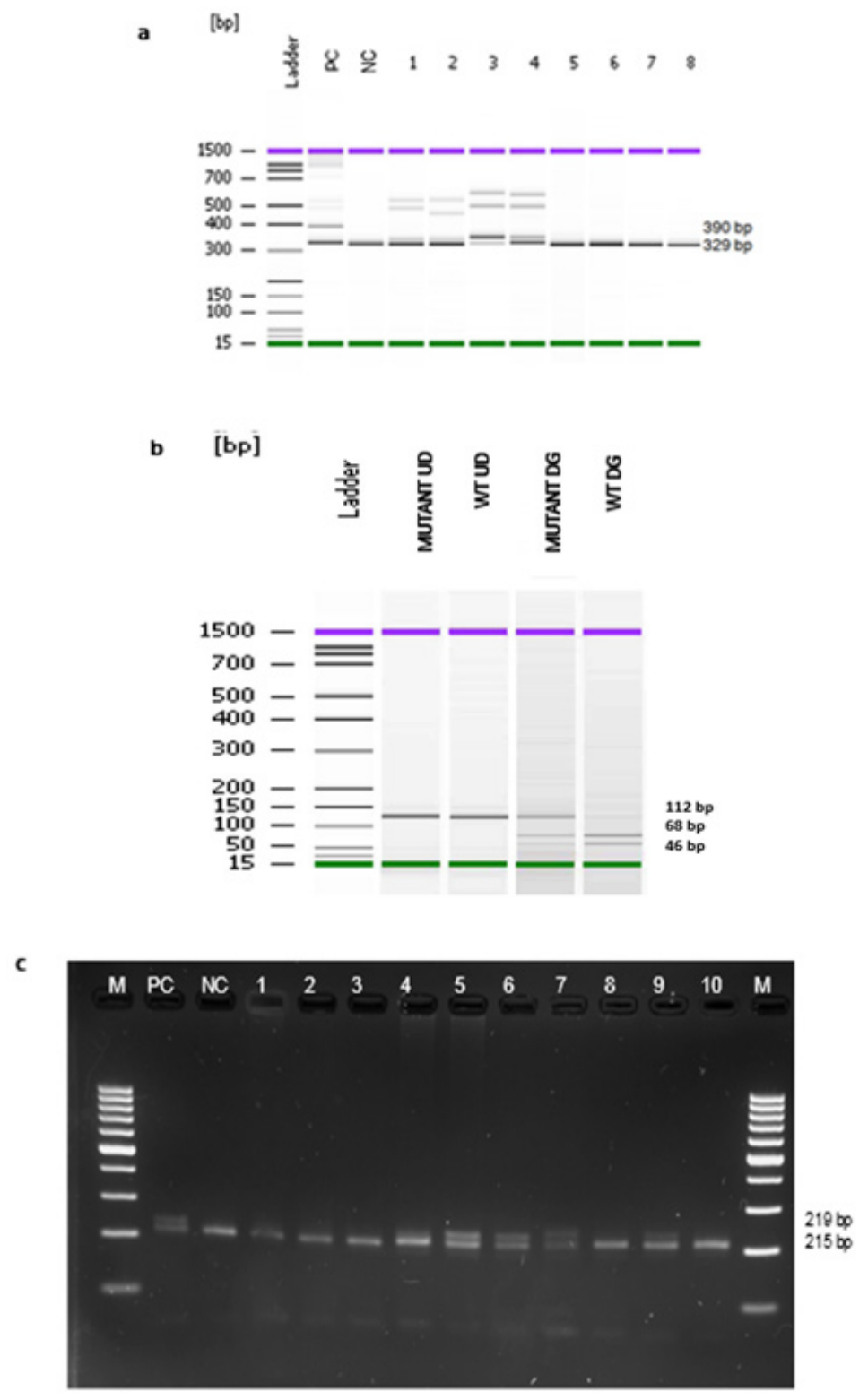

Figure 1. (a), PCR amplification results for FLT3-ITD gene mutation. Ladder: DNA marker (100 bp ladder), PC: Positive control, NC: negative control, Lane 1-4: Positive result, Lane 5-8: Negative result; (b), PCR amplification results for FLT3-D835 gene mutation. Ladder: DNA marker (100 bp ladder), Mutant UD: Mutant (Undigested), WT UD: wild type (Undigested), Mutant DG: Mutant (Digested), WT DG: wild type (Digested); (c), PCR amplification results for NPM1 gene mutation. Lane M: DNA marker (100 bp ladder), Lane PC: Positive control, Lane NC: Negative control, Lane 4 - 7, 9: Positive result, Lane 1-3, 8, 10: Negative result. 

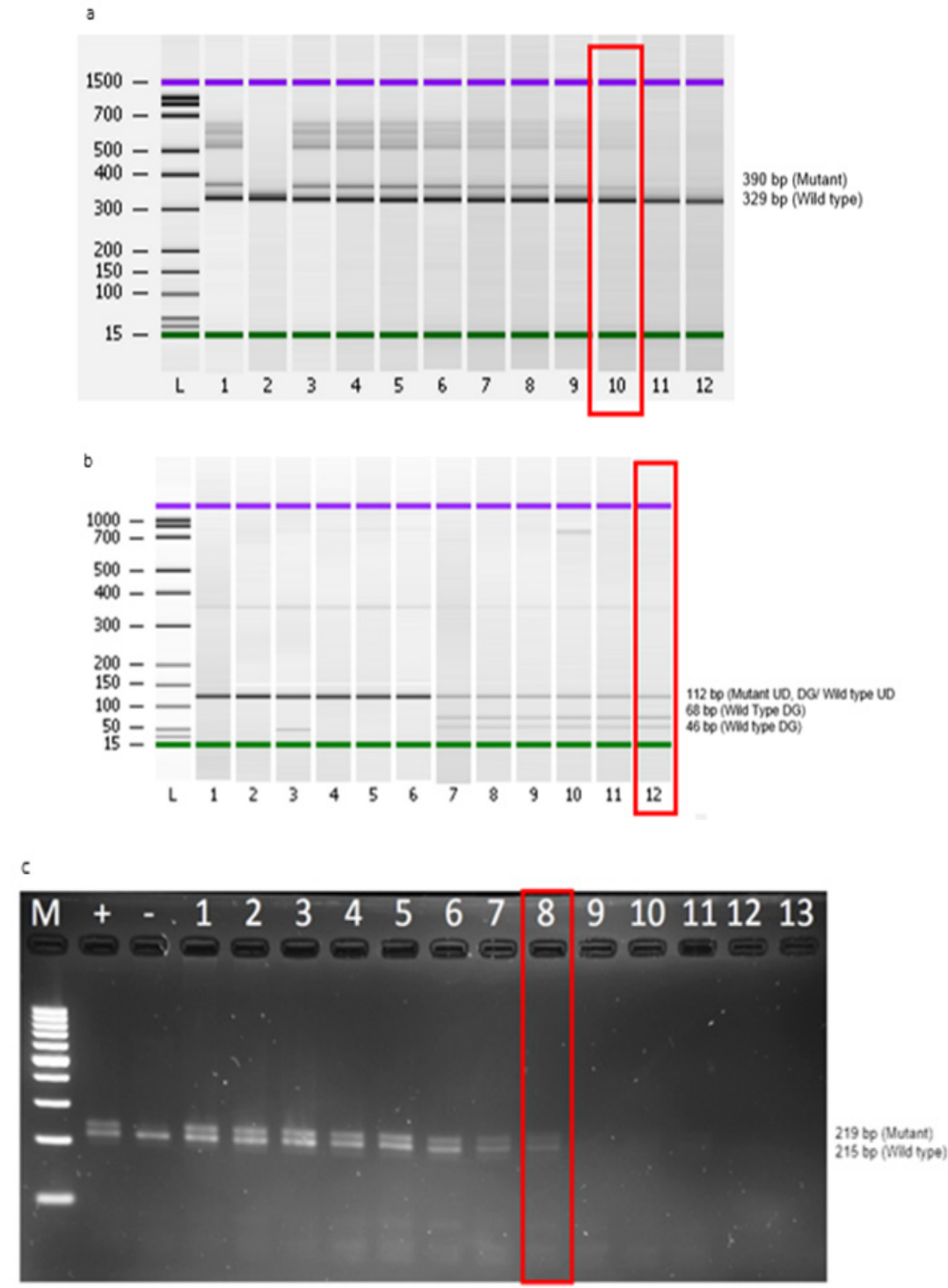

igure 2. (a), Testing limit of detection on FLT3-ITD primers. L: DNA marker (100 bp ladder), 1: Positive control (PC), 2: No template control (NTC), 3: $50 \mathrm{ng}, 4: 25 \mathrm{ng}, 5: 12.5 \mathrm{ng}, 6: 6.25 \mathrm{ng}, 7: 3.13 \mathrm{ng}, 8: 1.56 \mathrm{ng}, 9: 0.78 \mathrm{ng}, 10$ : $0.40 \mathrm{ng}, 11: 0.20 \mathrm{ng}, 12: 0.10 \mathrm{ng}$; (b), Testing for detection limitations of FLT3-D835 primers. L: DNA marker (100 bp ladder), 1: $50 \mathrm{ng}, 2: 25 \mathrm{ng}, 3: 12.5 \mathrm{ng}, 4: 6.25 \mathrm{ng}, 5: 3.13 \mathrm{ng}, 6: 1.56 \mathrm{ng}, 7: 50 \mathrm{ng}, 8: 25 \mathrm{ng}, 9: 12.5 \mathrm{ng}, 10: 6.25$ ng, 11: 3.13 ng, 12:1.56 ng; 1-6: Undigested samples, 7-12: Digested samples; (c), Testing for detection limitations of NPM1 primers. M: DNA marker (100 bp ladder), Lane +: Positive control (PC), Lane -: Negative control (NC), 1: $200 \mathrm{ng}, 2: 100 \mathrm{ng}, 3: 50 \mathrm{ng}, 4: 25 \mathrm{ng}, 5: 12.5 \mathrm{ng}, 6: 6.25 \mathrm{ng}, 7: 3.13 \mathrm{ng}, 8: 1.56 \mathrm{ng}, 9: 0.78 \mathrm{ng}, 10: 0.39 \mathrm{ng}, 11: 0.19$ ng, 12: $0.09 \mathrm{ng}, 13: 0.04 \mathrm{ng}$.

Table 1. Demographic Data and Types of Mutations in CN-AML Patients

\begin{tabular}{|c|c|c|c|c|c|c|}
\hline \multirow[t]{2}{*}{ Parameter } & \multirow{2}{*}{$\begin{array}{l}\text { All CN-AML patients } \\
\mathrm{n}=199\end{array}$} & \multirow{2}{*}{$\begin{array}{l}\text { CN-AML without } \\
\text { mutation } n=131\end{array}$} & \multicolumn{4}{|c|}{ CN-AML with mutations } \\
\hline & & & $\begin{array}{c}\text { FLT3-ITD } \\
\mathrm{n}=32\end{array}$ & $\begin{array}{c}\text { FLT3-D } 835 \\
\mathrm{n}=5\end{array}$ & $\begin{array}{l}N P M 1 \\
\mathrm{n}=54\end{array}$ & $\begin{array}{c}\text { FLT3-ITD and NPMI } \\
\mathrm{n}=23\end{array}$ \\
\hline \multicolumn{7}{|l|}{ Gender, N (\%) } \\
\hline Male & $104(52.3)$ & $77(58.8)$ & $14(43.8)$ & $2(40.0)$ & $20(37.0)$ & $9(39.1)$ \\
\hline Female & $95(47.7)$ & $54(41.2)$ & $18(56.3)$ & $3(60.0)$ & $34(63.0)$ & $14(60.9)$ \\
\hline \multicolumn{7}{|l|}{ Race, N (\%) } \\
\hline Malay & $102(51.3)$ & $64(48.9)$ & $19(59.4)$ & $3(60.0)$ & $28(51.9)$ & $12(54.5)$ \\
\hline Chinese & $57(28.6)$ & $43(32.8)$ & $4(12.5)$ & $0(0.0)$ & $13(24.1)$ & $3(13.6)$ \\
\hline Indian & $12(6.0)$ & $8(6.1)$ & $3(9.4)$ & $0(0.0)$ & $4(7.4)$ & $3(13.6)$ \\
\hline Others & $28(14.1)$ & $16(12.2)$ & $6(18.8)$ & $2(40.0)$ & $9(16.7)$ & $5(18.2)$ \\
\hline \multicolumn{7}{|l|}{ Age } \\
\hline Mean years (range) & $46.16(16-83)$ & $44.99(16-83)$ & $48.28(18-71)$ & $51(21-68)$ & $49.31(18-68)$ & $50.73(18-67)$ \\
\hline
\end{tabular}


Table 2. Comparison of Clinical Parameters among Mutated and Non-Mutated Groups

\begin{tabular}{|c|c|c|c|c|c|c|}
\hline \multirow[t]{2}{*}{ Clinical characteristics } & \multirow{2}{*}{$\begin{array}{c}\text { All CN-AML } \\
\text { patients } n=199\end{array}$} & \multirow{2}{*}{$\begin{array}{c}\text { CN-AML } \\
\text { without } \\
\text { mutations } n=131\end{array}$} & \multicolumn{4}{|c|}{ CN-AML with mutations } \\
\hline & & & $\begin{array}{c}\text { FLT3-ITD } \\
\mathrm{n}=32\end{array}$ & $\begin{array}{c}\text { FLT3-D835 } \\
\mathrm{n}=5\end{array}$ & $\begin{array}{l}N P M 1 \\
\mathrm{n}=54\end{array}$ & $\begin{array}{c}\text { FLT3-ITD \& NPMI } \\
\mathrm{n}=23\end{array}$ \\
\hline \multirow{2}{*}{$\begin{array}{l}\text { Median Hb level, } \\
\text { g/dl (range) }\end{array}$} & \multirow[t]{2}{*}{$8.83(1.1-18.5)$} & \multirow[t]{2}{*}{$9.06(1.1-18.5)$} & $8.49(4.0-13.5)$ & $8.52(7.1-9.8)$ & $8.46(6.2-13.5)$ & $8.68(6.3-13.5)$ \\
\hline & & & $\mathrm{p}=0.391$ & $\mathrm{p}=0.772$ & $\mathrm{p}=0.094$ & $\mathrm{p}=0.759$ \\
\hline \multirow{2}{*}{$\begin{array}{l}\text { Median WBC count, } \\
1 \mathrm{X} 10^{9} / \mathrm{L} \text { (range) }\end{array}$} & \multirow[t]{2}{*}{$48.18(1.8-150)$} & \multirow[t]{2}{*}{$47.28(1.8-150)$} & $53.356(6.1-150)$ & $87.72(5.3-150)$ & $45.5(4.3-150)$ & $54.00(6.1-150)$ \\
\hline & & & $\mathrm{p}=0.487$ & $\mathrm{p}=0.274$ & $\mathrm{p}=0.961$ & $\mathrm{p}=0.530$ \\
\hline \multirow{2}{*}{$\begin{array}{l}\text { Median platelet count, } \\
1 \times 10^{9} / \mathrm{L} \text { (range) }\end{array}$} & \multirow[t]{2}{*}{$143.70(15.2-736)$} & \multirow[t]{2}{*}{$159.46(15.2-736)$} & $112.53(16-368)$ & $193.6(105-335)$ & $111.04(20-390)$ & $124.82(54-368)$ \\
\hline & & & $\mathrm{p}=0.024$ & $\mathrm{p}=0.376$ & $\mathrm{p}=0.006$ & $\mathrm{p}=0.273$ \\
\hline
\end{tabular}

32 patients $(16.1 \%)$, FLT3-D835 in $5(2.5 \%)$ and NPM1 in $54(27.1 \%)$, while double mutations of NPM1 and FLT3-ITD were detected in $23(11.6 \%)$. Assays validation were performed on all PCR-positive and 30 PCR-negative samples using Sanger sequencing, which showed 100\% conformity with FLT3-ITD, FLT3-D835 and NPM1 mutation genes.

Clinical characteristics of CN-AML patients were analysed by comparing these four groups (Table 2). Haemoglobin (Hb) level in the FLT3-ITD and NPMI mutations was significantly lower as compared to the group without mutations. Clinical parameters of the groups with FLT3-D835 and those who had both FLT3-ITD and NPM1 positivity were not significantly different from group without mutations, probably due to the smaller number of patients.

\section{Discussion}

FLT3 and NPM1 gene mutations testing by commercialized kits are relatively expensive. This has led us to develop a simple, reliable and cost effective in-house conventional PCR method for rapid detection of these mutations. CN-AML patients may benefit from FLT3 and NPM1 gene mutation testings as it provides useful information on patient prognosis and assist clinical decision for personalised treatment. During the lasts decades, a wide variety of methods have been developed for detection of FLT3 and NPM1 mutations such as genomic DNA sequencing of different mutation-specific RT-PCR assays, denaturing high-performance liquid chromatography, capillary electrophoresis, allele-specific oligonucleotide polymerase chain reaction (ASO-PCR) and high-resolution melting analysis (Ammatuna et al., 2005; Chopra et al., 2016; Lu et al., 2012; Noguera et al., 2005; Ottone et al., 2008; Tan et al., 2008).

Commercial kit-based assays were used because they are reproducible, validated and certified. Procedures for commercialized kits are also less labour intensive, does not require in-depth molecular biology skills and experience as required for in-house assay development. However, commercial kit-based assays incur a higher cost to procure reagents and equipment since there is a lack of universal compatibility with real-time PCR platforms. Conventional PCR assay has been widely used as a diagnostic tool since it is simple, more cost-effective. Development of in-house assays are beneficial in term of platform compatibility and relatively more economical as compared to kits, although the assays are certainly more labour intensive specifically at the standardisation stages which require rigorous validation protocol.

FLT3 gene mutation has negative impact on adult and childhood AML (Hollink et al., 2009; Kiyoi et al., 1999). This gene is important for cell survival, proliferation and differentiation of haematopoietic cells. Thus, mutation on this gene may disturb the balance between cell proliferation and differentiation. FLT3 gene mutation causes the activation of tyrosine kinase receptor which causes multiple downstream signalling pathways and leads to leukaemogenesis (Grafone et al., 2012).

FLT3 gene mutations are found in 25 to $45 \%$ among AML patients and FLT3-ITD mutations are found in approximately 20 to 37\% (Auewarakul et al., 2005; Burnatt et al., 2017). FLT3-D835 mutations are found to be less common as compared to FLT3-ITD mutations with the percentage of 5.8 to $7.7 \%$. NPM1 mutations at exon 12 are the most common genetic abnormality in AML, found in approximately 24 to $45 \%$ of all AML cases and up to $60 \%$ of adult CN-AML (Falini et al., 2005; Döhner et al., 2005; Weina et al., 2006).

From the total of $199 \mathrm{CN}-\mathrm{AML}$ patients in this study, FLT3-ITD, FLT3-D835 and NPM1 mutations were detected in $16.1 \%(32 / 199), 2.5 \%(5 / 199)$, and $27.1 \%(54 / 199)$ respectively. These findings are lower than reported among CN-AML in German (31 to 32\% FLT3-ITD, 11 to $14 \%$ FLT3-D835, 45.7 to $53 \%$ NPM1) (Frohling et al., 2002; Schlenk et al., 2008; Thiede et al., 2006), United States (34.6\% FLT3-ITD, 7.4\% FLT3-D835) (Whitman et al., 2008), United Kingdom (34\% FLT3-ITD, 62\% NPM1) (Gale et al., 2008) and Japan (47.4\% NPM1) (Suzuki et al., 2005). Frequency of FLT3-ITD and FLT3-D835 in our study was comparable to a preliminary study conducted by (Dehbi et al., 2013) in CN-AML patients (18.2\% FLT3-ITD, 3\% FLT3-D835). Previous study reported that mutations of FLT3-ITD in adults are higher than children. This finding may partially explain a poorer prognosis in adult than childhood $A M L$ (Frohling et al., 2002).

Identification of FLT3 and NPM1 gene mutations might help clinician to provide proper treatment for the patients. In this study, PCR assays for the detection of FLT3-ITD, FLT3-D835 and NPM1 were successfully developed. The use of bioanalyzer as detection method for PCR amplicons reduces the workload as it involves simple procedures. Sanger sequencing was performed for validation of these assays. Analytically, the developed FLT3-ITD, FLT3-D835 and NPM1 PCR assays have lower limit of detection of $0.4 \mathrm{ng}, 1.56 \mathrm{ng}$ and $1.56 \mathrm{ng}$ 
respectively, which was slightly better compared to other study (Liu et al., 2015). Our in-house PCR assays are reliable, requires small volume of samples, less labour intensive with shorter turnaround time and cost effective.

In conclusion identification of FLT3-ITD, FLT3-D835 and NPM1 mutations in CN-AML are important for prognostication, treatment decision and optimization of patient care. Therefore, the use of these PCR assays as diagnostic tool is a practical approach for mutation detection in $A M L$ as it is simple, robust and cost effective.

\section{Acknowledgements}

The authors would like to thank the Director General of Health Malaysia for his permission to publish this article. This work was funded by Ministry of Health, Malaysia (grant: JPP-IMR: 13-053/ NMRR-13-952-17980). The authors would like to declare that there was no conflict of interest in this study.

\section{References}

Abu-Duhier FM, Goodeve AC, Wilson GA, et al (2001). Identification of novel FLT-3 Asp835 mutations in adult acute myeloid leukaemia. Br J Haematol, 113, 983-8.

Alpermann T, Schnittger S, Eder C, et al (2016). Molecular subtypes of NPM1 mutations have different clinical profiles, specific patterns of accompanying molecular mutations and varying outcomes in intermediate risk acute myeloid leukemia. Haematologica, 101, 55-8.

Ammatuna E, Noguera NI, Zangrilli D, et al (2005). Rapid detection of nucleophosmin (NPM1) mutations in acute myeloid leukemia by denaturing HPLC. Clin Chem, 51, 2165-7.

Auewarakul CU, Sritana N, Limwongse C, et al (2005). Mutations of the FLT3 gene in adult acute myeloid leukemia: determination of incidence and identification of a novel mutation in a Thai population. Cancer Genet Cytogenet, 162, 127-34.

Borer RA, Lehner CF, Eppenberger HM, et al (1989). Major nucleolar proteins shuttle between nucleus and cytoplasm. Cell, 56, 379-90.

Burnatt G, Licínio MA, Gaspar PC, et al (2017). Analysis of the presence of FLT3 gene mutation and association with prognostic factors in adult and pediatric acute leukemia patients. Braz J Pharm Sci, 53, e16105.

Chirayu UA, Narongrit S, Chanin L, et al (2005). Mutation of FLT3 gene in adult acute myeloid leukemia: determination of incidence and identification of a novel mutation in a Thai population. Cancer Genet Cytogenet, 162, 127-34.

Chopra A, Soni S, Pati H, et al (2016). Nucleophosmin mutation analysis in acute myeloid leukaemia: Immunohistochemistry as a surrogate for molecular techniques. Indian J Med Res, 143, 763-8.

Dehbi H, Kassogue Y, Nasserddine S, et al (2013). FLT3-ITD Incidence and FLT-D835 Mutations in Acute Myeloid Leukemia Patients with Normal Karyotype in Morocco: A Preliminary Study. Middle East J Cancer, 4, 1-5.

Dohner H, Estey EH, Amadori S, et al (2010). Diagnosis and management of acute myeloid leukemia in adults: recommendations from an international expert panel, on behalf of the European LeukemiaNet. Blood, 115, 453-74.

Dunna NR, Rajappa S, Digumarti R, et al (2010). Fms like tyrosine kinase (FLT3) and nucleophosmin 1 (NPM1) mutations in de novo normal karyotype acute myeloid leukemia (AML). Asian Pac J Cancer Prev, 11, 1811-6.

Estey E, Dohner H (2006). Acute myeloid leukaemia. Lancet, 368, 1894-907.

Falini B, Mecucci C, Tiacci E, et al (2005). Cytoplasmic nucleophosmin in acute myelogenous leukemia with a normal karyotype. $N$ Engl J Med, 352, 254-66.

Frohling S, Schlenk RF, Breitruck J, et al (2002). Prognostic significance of activating FLT3 mutations in younger adults (16 to 60 years) with acute myeloid leukemia and normal cytogenetics: a study of the AML Study Group Ulm. Blood, 100, 4372-80.

Gale RE, Green C, Allen C, et al (2008). The impact of FLT3 internal tandem duplication mutant level, number, size, and interaction with NPM1 mutations in a large cohort of young adult patients with acute myeloid leukemia. Blood, 111, 2776-84.

Grafone T, Palmisano M, Nicci C, et al (2012). An overview on the role of FLT3-tyrosine kinase receptor in acute myeloid leukemia: biology and treatment. Oncol Rev, 6, e8.

Grimwade D, Hills RK, Moorman AV, et al (2010). Refinement of cytogenetic classification in acute myeloid leukemia: determination of prognostic significance of rare recurring chromosomal abnormalities among 5876 younger adult patients treated in the United Kingdom Medical Research Council trials. Blood, 116, 354.

Hayakawa F, Towatari M, Kiyoi H, et al (2000). Tandem-duplicated Flt3 constitutively activates STAT5 and MAP kinase and introduces autonomous cell growth in IL-3-dependent cell lines. Oncogene, 19, 624-31.

Hollink IH, Zwaan CM, Zimmermann M, et al (2009). Favorable prognostic impact of NPM1 gene mutations in childhood acute myeloid leukemia, with emphasis on cytogenetically normal AML. Leukemia, 23, 262-70.

Ivey A, Hills RK D Phil, Simpson MA, et al (2016). Assessment of minimal residual disease in standard-risk AML. $N$ Engl $J$ Med, 374, 422-33

Kiyoi H, Naoe T, Nakano Y, et al (1999). Prognostic implication of FLT3 and $N-R A S$ gene mutations in acute myeloid leukemia. Blood, 93, 3074-80.

Levis M (2013). FLT3 mutations in acute myeloid leukemia: what is the best approach in 2013?. Hematol Am Soc Hematol Educ Program, 2013, 220-6.

Liu HE, Ko C-H, Lam F, et al (2015). Establishment of a costeffective method to detect FLT-ITD and D835 mutations in acute myeloid leukaemia patients in the Taiwanese population. Tzu Chi Med J, 27, 18-24.

Lowenberg B, Downing JR, Burnett A (1999). Acute myeloid leukemia. $N$ Engl J Med, 341, 1051-62.

Lu Y, Wang Q, Mu QT, et al (2012). Establishment of a rapid and easy method for simultaneous detection of FLT3-ITD and NPM1 gene mutations in acute myeloid leukemia. Zhonghua Yi Xue Yi Chuan Xue Za Zhi, 29, 163-6.

Markovic A, MacKenzie KL, Lock RB (2005). FLT-3: a new focus in the understanding of acute leukemia. Int J Biochem Cell Biol, 37, 1168-72.

Mrozek K, Heerema NA, Bloomfield CD (2004). Cytogenetics in acute leukemia. Blood Rev, 18, 115-36.

Morris SW, Kirstein MN, Valentine MB, et al (1994). Fusion of a kinase gene, ALK, to a nucleolar protein gene, NPM, in non-Hodgkin's lymphoma. Science (New York, NY), Science, 263, 1281-4.

Noguera NI, Ammatuna E, Zangrilli D, et al (2005). Simultaneous detection of NPMI and FLT3-ITD mutations by capillary electrophoresis in acute myeloid leukemia. Leukemia, 19, 1479-82.

Ottone T, Ammatuna E, Lavorgna S, et al (2008). An allele-specific RT-PCR assay to detect type a mutation of 
the Nucleophosmin-1 gene in acute myeloid leukemia. J Mol Diagn, 10, 212-6.

Renneville A, Roumier C, Biggio V, et al (2008). Cooperating gene mutations in acute myeloid leukemia: a review of the literature. Leukemia, 22, 915-31.

Schlenk RF, Dohner K, Krauter J, et al (2008). Mutations and treatment outcome in cytogenetically normal acute myeloid leukemia. N Engl J Med, 358, 1909-18.

Shipley JL, Butera JN (2009). Acute myelogenous leukemia. Exp Hematol, 37, 649-58.

Suzuki T, Kiyoi H, Ozeki K, et al (2005). Clinical characteristics and prognostic implications of NPM1 mutations in acute myeloid leukemia. Blood, 106, 2854-61.

Tan AY, Westerman DA, Carney DA, et al (2008). Detection of NPM1 exon 12 mutations and FLT3 - internal tandem duplications by high resolution melting analysis in normal karyotype acute myeloid leukemia. J Hematol Oncol, 1, 10.

Thiede C, Koch S, Creutzig E, et al (2006). Prevalence and prognostic impact of NPM1 mutations in 1485 adult patients with acute myeloid leukemia (AML). Blood, 107, 4011-20.

Verhaak RG, Goudswaard CS, van Putten W, et al (2005). Mutations in nucleophosmin (NPM1) in acute myeloid leukemia (AML): association with other gene abnormalities and previously established gene expression signatures and their favorable prognostic significance. Blood, 106, 3747-54.

Wang L, Lin D, Zhang X, et al (2005). Analysis of FLT3 internal tandem duplication and D835 mutations in Chinese acute leukemia patients. Leuk Res, 29, 1393-8.

Whitman SP, Ruppert AS, Radmacher MD, et al (2008). FLT3 $D 835 / 1836$ mutations are associated with poor disease-free survival and a distinct gene-expression signature among younger adults with de novo cytogenetically normal acute myeloid leukemia lacking FLT3 internal tandem duplications. Blood, 111, 1552-9.

$\mathrm{Xu} \mathrm{B}$, Li L, Tang JH, et al (2005). Detection of FLT3 gene and FLT3/ITD mutation by polymerase chain reaction-single-strand conformation polymorphism in patients with acute lymphoblastic leukemia. Di Yi Jun Yi Da Xue Xиe Bao, 25, 1207-10.

Yamamoto Y, Kiyoi H, Nakano Y, et al (2001). Activating mutation of D835 within the activation loop of FLT3 in human hematologic malignancies. Blood, 97, 2434-9.

\section{c) (7) (8)}

This work is licensed under a Creative Commons AttributionNon Commercial 4.0 International License. 